eCommons@AKU

Book Chapters

January 2008

\title{
Curriculum reform in science education in Pakistan
}

Nelofer Halai

Aga Khan University, nelofer.halai@aku.edu

Follow this and additional works at: http://ecommons.aku.edu/book_chapters

Part of the Elementary and Middle and Secondary Education Administration Commons, Elementary Education and Teaching Commons, Junior High, Intermediate, Middle School Education and Teaching Commons, Science and Mathematics Education Commons, and the Secondary Education and Teaching Commons

\section{Recommended Citation}

Halai, N. (2008). Curriculum reform in science education in Pakistan. Science education in context: An international examination of the influence of context on science curricula development and implementation, 115-129.

Available at: http://ecommons.aku.edu/book_chapters/109 


\title{
CURRICULUM REFORM IN SCIENCE EDUCATION IN PAKISTAN
}

\begin{abstract}
INTRODUCTION
Pakistan, like many countries in the region inherited its system of education from the British. Lord Macaulay (1835, Minutes on Education) aspired to make Indians into 'Brown Sahibs' who would mimic the British in dress, food and mannerisms, but who would lack the intellect to forge ahead on their own. Thus both the Hindus and Muslims of the sub-continent would become the 'workhorses' of the empire, and would do the bidding of the conquerors. As a consequence the system of education that the British installed produced not individuals who could think for themselves, but clerical staff who could deal with the bureaucracy of the Raj. Very little attention was paid to science education, and it was only included in the curriculum at the secondary level after the formation of Pakistan in 1947. This chapter provides a picture of science education in Pakistan, and examines how the gaps in science education were addressed with the help of huge investment in practical science teaching, but how this effort has not born fruit. Lastly, some ways in which science education might be enhanced and improved in Pakistan are proposed.
\end{abstract}

\section{SCIENCE EDUCATION: POST PARTITION TO DATE}

In 1947 the Indian subcontinent was divided into two countries, the Muslim majority provinces in the Northwest and Northeast of India was called (East and West) Pakistan and the rest became India. East Pakistan became Bangladesh and West Pakistan, became Pakistan. Since, its inception Pakistan has been disadvantaged as majority of universities and schools were in the territory that now comprise modern day India. However, through a huge effort Pakistan has enhanced its education sector, and there are now more than 100 institutions of higher education (Isani, 2002) and a literacy rate of more than 50\% (World Bank, 2007). From the outset, science and technology were seen as a way to allow the young Muslim state to enter the twentieth century, and a concerted effort was made to improve the teaching and learning in science through the use of innovative strategies (Warwick \& Reimers, 1995).

Until the 1950s science was taught only in post-secondary institutions, and very little science was taught at the primary and secondary school levels (Iqbal \& Mamood, 2000). The topic nature study was introduced into primary classes in 1959 and, in principle, general science and mathematics were compulsory for 
Grades 1 to 8 . But the implementation of science remained difficult, and the thrust of education in general focused more on the liberal arts.

More ambitious curriculum reforms, particularly in the area of active science learning, were initiated in the 1970s when practical work was first introduced in school curricula at Grades 9 to 12. In 1972 the new education policy of the Pakistan Government represented a massive shift from a general, to a more technical and scientific education, at the secondary and higher secondary school levels. However, appropriate long term planning was not undertaken. As a result, a severe shortage of science teachers at the time was solved by rather ad-hoc measures, such as inducting untrained teachers (or teachers with minimal qualifications in science) into the profession. This resulted in a dramatic drop in the standard of science teaching. In 1979 governmental education policy documents acknowledged this gap in educational planning, and observed that no system could be better than its teachers. Efforts were subsequently made with the help of loans from the Asian Development Bank to develop new science curricula. A new body called the Institute for the Promotion of Science Education and Training (IPSET) was established for in-service training of science teachers. Although these efforts helped to increase the profile of science in the school curriculum, science teaching remained rooted in the past for a number of reasons, which are discussed below.

In 2002 the Pakistan Higher Education Commission (HEC) was formed under the charismatic leadership of Dr. Attaur Rahman. Dr. Rahman was able to enhance the funding for higher education substantially, and a Task Force on Higher Education was formed. A large number of the Taskforce recommendations to improve the standard of education generally, and science education in particular, were accepted and are in the process of implementation as of 2007. However, none of these efforts questioned basic assumptions about practical work in science. It has been assumed, for example, that 'more of the same' will be effective in improving science learning, and hence the focus has been on improving practical work in the same way as practiced in the past, through provision of more laboratories and other resources. However, fundamental questions and issues about practical work have not been addressed, and these haunt science education in Pakistan. Some of the challenges facing practical work are specific to Pakistan; others are more general and impinge on the way practical work is envisaged all over the world.

Pakistan engaged in 'post-Sputnik' reform efforts in science education, and practical work in science was made compulsory for Grades 9 to 12. Every examination of science learning in schools includes a 'score' for practical work and this comprises $25 \%$ of the total marks. So, for example, a student assessed for physics at say Grade 10 would be allocated 75 out of 100 marks for a pencil and paper type test, and 25 marks from a hands-on practical examination in a laboratory. A large amount of funds were spent on teacher training, and for procuring science kits and other materials necessary for practical work. This was done with high hopes of increasing Pakistan's human resources in science and technology. However, the reforms have not produced the desired results. Practical work consists of activities that verify known scientific principles, or to illustrate scientific processes. The context of teaching and learning in the schools is such that 
even these activities are reduced to the level of rote memorization of the steps needed to complete 'the practical'. Hence, this form of practical work has not really helped Pakistani students develop understanding of scientific concepts or an understanding of 'doing science'.

\section{CHALLENGES FACING SCIENCE EDUCATION IN PAKISTAN}

The problems facing science education in Pakistan are two-pronged. One is the 'deficiency' problem that dominates many developing countries with limited resources. This results in consequential problems that include: (a) a shortage of science teachers, (b) poor training of science teachers, (c) poor quality of textbooks, (d) a system of examinations that encourages rote memorization, and (e) a lack of laboratories, equipment, and other resources needed to teach science. However, there is a deeper problem in Pakistan that I call the 'conceptualization problem'. The conceptualization of science education Pakistan requires us to ask questions such as, 'What kind of science education is needed for Pakistan?', 'What kind of practical work is needed for Pakistani students?' and 'What are the skills that we need to teach students through practical work in science?'. These have been left largely unanswered.

I first discuss briefly the deficiency challenges faced by Pakistan science teachers and educators as this relates to practical work, and then consider the conceptual difficulties and some ways I think we can address them.

\section{Training of Science Teachers}

Teaching science at different grade levels in Pakistan, as elsewhere requires different levels of specialization. The emphasis at earlier stages in Pakistan is on pedagogical skills of teachers, and their ability to convey concepts and ideas to students. Up to say Grade 5, after 10 years of schooling, primary certificate level training only is required. To teach Grades 6 to 8 requires a general certificate after 12 years of schooling. At higher levels, more advanced subject knowledge and technical expertise in the laboratory is required, in the form of BSc and BEd degree qualifications. Hence, primary level teachers with only 10-12 years of schooling are not able to do justice to the teaching of science. As in many other parts of the world, Pakistani primary teachers do not necessarily have an academic background in science, and yet are expected to teach science at the primary level. Not surprisingly, Pakistan primary school teachers often lack confidence about teaching science. Their teaching is at best textbook-based.

In addition, the training and practice teaching for Pakistan science teachers leaves much to be desired. Most of the pedagogy of science is taught via lectures and, rather ironically, pre-service teacher trainees are exhorted to use activitybased methods in science in these lectures. Hence, 'trained' teachers of science usually do not have much idea of how to teach through 'activity means', or about classroom management issues that often occur when more exciting activities or 
demonstrations are done in class. There has been a huge growth in the private education sector in Pakistan involving teacher training through private universities either in Pakistan or abroad. This has led to some improvement in science teaching in some private schools, but key core questions that affect science education and particularly practical work in Pakistan remain.

\section{Shortage of Science Teachers}

There is a significant shortage of science teachers in Pakistan. Statistics even for the largest and the most developed province of Pakistan show that at the elementary level one science teacher per school is the norm, while at the secondary level three science teachers is the norm (Social Policy \& Development Center [SPDC], 2002-03). The situation is much worse in rural areas, and in rural Pakistan many primary schools have no science teachers, and most secondary school science teachers do not possess a degree in science. It is not unusual to find those teaching science who have never studied science in school. However, in large cities such as Karachi, it not difficult to find teachers who teach science at the secondary and middle school levels who have a BSc or MSc.

This shortage of science teacher then creates two kinds of problems, science teachers who are available are expected to teach a large number of classes, and cannot do justice to their teaching. Instead they tend to focus on covering the syllabi for the examinations. Second, science teachers, particularly at the college level, are expected to teach very large classes, often of more than 100 students, meaning it is not possible for the teacher to communicate well with students, let alone teach them well.

\section{Quality of Science Textbooks}

In many developing countries textbooks are often the only resource other than the teacher that the students can utilize in learning science. Hence, science textbook are even more important in science learning than in developed nations. "An examination of prescribed textbooks for secondary and higher secondary schools reveals that they:

- present science in a manner that is too abstract and formal;

- are deficient in content as well in presentation;

- $\quad$ are lacking in focus and precision that is essential in understanding and working with scientific phenomena; and

- are unsuitable in terms of developing concepts and creating and maintaining the interest of the students" (SPDC, 2002-03, p. 140).

In Pakistan, as elsewhere, textbooks lay a great deal of emphasis on definitions and facts rather than developing conceptual understanding of ideas. Nor do they try to make coherent the big ideas in science (American Association for the Advancement of Science [AAAS], 1993) so that students can, for example, see that 
light, magnetism and heat are all different forms of energy, all of which are governed by the same principles.

In Pakistan even after completing a science masters degrees the graduates who may become teachers may not develop conceptual understanding or and analytical capability in science, and are often unable to draw graphs, read and interpret data or otherwise analyze scientific data. Hence, poorly prepared graduates often become poor science teachers, who in turn teach inadequately in a cycle that reinforces a limited view of science.

\section{Assessment of Science Learning}

Secondary and higher secondary examinations in Pakistan are centralized, conducted by multiple boards of education, and set for this purpose in each province. The Federal Government of Pakistan also has a Board of Examination for schools under its gambit. The examinations occupy a central position in both students' and teachers' lives in both schools and colleges. Teaching approaches in the classroom, the assessment system in schools, the textbooks prescribed, and students' and teachers' attitudes towards teaching and learning are strongly influenced, if not governed, by these Board examinations (Halai, 2002). Schools and colleges are assessed, and assess themselves, on the basis of their students' performance in these exams. This would be acceptable if the examinations at least attempted to test conceptual understanding, reasoning ability or the ability to problem-solve. However, the question papers are structured in a very specific way, meaning those who teach to these examinations are rewarded. Only about $33 \%$ is required to gain an examination 'pass', meaning students need to know relatively little of the topics covered in the syllabus.

Competition for entry into each grade of study is very stiff, and this has given rise to the phenomenon of teaching Grades 9 and 10 science in Grade 8, and sometimes even in Grade 7, whether or not students are prepared for study at these levels. As an illustration, there is no requirement to use symbols and equations to denote chemical reactions in Grades 7 and 8 . So the reaction between carbon and oxygen would be represented thus:

$$
\text { Carbon }+ \text { oxygen } \rightarrow \text { carbon dioxide }
$$

However, many science teachers in the school expect the students to write it such an equation using symbols in the form,

$$
\mathrm{C}+\mathrm{O}_{2} \rightarrow \mathrm{CO}_{2}
$$

and then teach the balancing of equations; thus expecting Grade 7 and 8 students to memorize symbols and valences for elements and radicals, along with the concept that equations are expressions of molar quantities taught in Grade 9. Such teaching encourages rote memorization undertaken in order to keep up with teaching for 
Grades 9 and 10. The examinations thus have become a test of memorization, and encourage even progressive schools to 'teach to the test'. Any efforts to bring about changes to teaching are resisted strongly both by parents and students because of the high stakes nature of the examinations.

\section{Poor Implementation of the Science Curriculum}

In Pakistan science is integrated up to Grade 8 after which the students are given the choice which stream to take, one of which is the science stream where the major branches, physics, chemistry, and biology, all taught as separate subjects. From a pedagogical standpoint, the argument in favor of integration is that that real life situations demand the application of scientific knowledge which is not 'compartmentalized' into physics, chemistry, or biology, but that exist as an integrated whole. In developing countries like Pakistan few students pursue higher education, and so a compulsory integrated science curriculum up to Grade 10 is deemed more appropriate. It is further argued that it is too early to stream at Grade 8 , and to do so would deny students in non-science streams valuable learning not covered in general science. In Pakistan, streaming into science starts as early as the end of Grade 8, and student performance in science and mathematics at this grade thus acts as a 'gatekeeper' to further science study. Science 'graduates' are privileged, in that they can then reenter any other stream such as art or commerce, but the reverse is not allowed.

The implementation of an integrated science curriculum is not without problems. The main problem lies with the teachers, their capabilities and their resistance to change. Pakistan teachers find it difficult to hold mastery of all disciplines of science such as physics, chemistry, biology, geology, and astronomy, especially considering that they typically specialize in only one field. It is argued that if the different branches of science are to be taught with some depth in Grades 9 and 10 , they must be handled by specialist teachers.

However, the weakest aspect of the science curriculum in Pakistan is probably in the implementation of the curriculum. The science curriculum documents overall are well written, but the resources necessary to put them into effect are simply not in place. Overall, the poor quality of the teachers is probably the major barrier to good science teaching in Pakistan.

\section{Lack of Science Laboratories and Resources}

A lack of availability of science laboratories for Grades 9-12 students is a cold reality in Pakistan, and much more needs to be done to ensure that the requisite materials are available to science teachers. However, it is also true that science teachers need to be empowered to obtain the required materials. It has been my experience that schools actually often have allocated funds which go unused, since no requests for materials are made by science teachers. Under-utilization of allocated funds is actually more of a problem in government schools than lack of 
funds. Additionally, the teaching of science in Grades 1 to 8 does not require much laboratory equipment. My work in teaching a science methods course for primary science teachers, suggests that using simple, readily available materials can lead to positive learning outcomes at this level (see Halai, 2002).

\section{NEEDED REFORM IN PRACTICAL WORK IN SCIENCE}

Practical work has the potential to deliver many benefits for students' learning of science (see, e.g., Nakleh, Polles \& Malina, 2002) in allowing hands-on experience of natural phenomena, but there are also limitations that need to be considered. There are a number of assumptions about practical work that need to be very carefully considered when designing practical activities (Halai, 2002). It is, for example, assumed that 'teaching science' 'doing science', and 'teaching about science' are much the same thing. Through these three aspects overlap I would argue that they are distinct.

\section{CHANGING CONCEPTIONS OF THE NATURE OF SCIENCE}

There is reasonable consensus among science educators all over the world that teaching about the nature of science should be a part of science curricula (see, e.g., AAAS, 1993). While this thinking has been taken on board in the Pakistan science curriculum tacitly, no attempt has been made to define it more explicitly, or to actually include it in teaching of science. Most science teachers in Pakistan have been exposed to a very positivist conception of science. As a consequence, many local teachers do not understand the nature of science themselves, and assume, for example, that observations are independent of theory, and also assume that all students observing a given phenomenon will see the same thing as the teacher. A related assumption is that practical work 'speaks for itself', and that after practical work no discussion of outcomes is necessary.

Pakistan science teachers often assume that students see what the teacher does while looking at a science demonstration. All students have to do is to see the activities, and they will inevitably abstract the same principle or concept that the teacher wants to illustrate. Roth $(1995$, p. 3) expressed similar views when he started to teach science: "I began to teach science assuming that all students had to do was to look and recognize the truth about nature; I assumed that what I saw happening in a test tube should be seen equally by students". Roth soon changed his views with experience! The reality is, of course, that students often see things very differently from their teachers. Teachers bring their own theoretical framework with them, and look at the particular activity with a specific lens that guides their observations. Not sharing that lens (because of their own more limited experiences), students often see things very differently from the teacher. Studies in which students are expected to draw the internal structure of a plant cell after observing it under a microscope show clearly that students often focus on something entirely different to that of the teacher. Hodson (1998, p. 10) sums up the theory-dependence of observation very succinctly: 
The traditional school curriculum description of science says two things about observation. First, nothing enters the mind of the scientist except by way of the senses - that is, the mind is a tabula rasa on which the senses inscribe a true and faithful record of the world. Second, the validity and reliability of the observation statements are independent of the opinions and expectations of the observer and can be readily confirmed by other observers. Neither is true. In reality, we interpret the sense data that enter our consciousness in terms of our prior knowledge, beliefs, expectations and experiences.

Chalmers (1999) agrees that theory precedes observation, and says it is false to claim that science starts with observation. Even with highly guided activities, students do not see 'eye-to-eye' with their teachers. For example, in a science class, the teacher was using balloons to show that air has weight, but the students instead focused on the color of the balloons seeing this as an important variable in the experiment. Gunstone (1991) comments that 'looking at things' is an active process, in which students check out their perceptions against their expectations. In fact, students' personal theories may lead them to reject particular conclusions, by way of denying the legitimacy of observations.

This is a boarder problem than practical science Pakistan. In the 1980s as part of the Learning in Science Project (LISP), Tasker and Osborne (1985, p. 27) investigated difficulties students face when learning science in the classroom. They concluded that:

- There was a disparity between the ideas children brought to the lesson and the ideas the teacher assumed that they would bring to it;

- There was a disparity between the scientific problem the teacher would have liked the children to investigate and what they took to be the problem;

- There was a disparity between the activity proposed by the teacher and the activity undertaken by the children, despite considerable teacher intervention; and

- There was a disparity between the children's conclusions, and the conclusions proposed by the teacher.

Tasker and Osborne (1985) argue that the teacher's intentions cannot be directly transferred to students; rather the teacher has to contrive to see if the mental constructions of the students match what the teacher wanted to convey. Further, they state that appreciation of the perception the learner brings to the classroom (among other things) is essential if the gap between the teacher's intentions and the students' learning is to be reduced. This sort of thinking, about the importance of student prior knowledge, is what led to the development of constructivism and learner-centered education (Wheatley, 1991). 


\section{Meaning Making in Practical Work}

Practical work in science, or 'using activities' has a long history in many parts of the world such as the United Kingdom (Wellington, 1998), but practical work was only introduced into Pakistan schools in the early 1960s (Iqbal \& Mahmood, 2000). While practical work can motivate, illustrate, clarify and enhance understanding, it also has the ability to confuse. Driver (1994) attributes this problem to a simplistic and empirical view of science that knowledge is based on observation, and that scientific laws are acquired by a process of induction from the 'facts' of sensory data. The cliché 'I do and I understand' is often used to support the use of practical work in science teaching. If children are to understand science concepts more than that is needed. Driver comments that the slogan 'I do and I understand', instead is more likely to become, 'I do and I am even more confused'! Many science teachers have a rather naïve trust in the ability of practical activities to expose students to sensory data that will help them to construct scientific concepts. They may believe, for example, that observations give reliable information about the world, rather than being interpretations of phenomena based on one's own views and prior knowledge.

There has been an effort to reappraise the use of practical work in science teaching (Hodson, 1990; Wellington, 1998), and engage in a fair assessment of what practical work can and cannot achieve (Millar, 1998; Nakhleh et al., 2002). Science teachers think of activities as cognitively effective tools for teaching science because students can 'see' what is happening. But sometimes these tools became more like 'fun-work' rather than an activity that actually enhances understanding. Thus meaning making in science is often considered to be complete once the practical work ends. In fact the end of the activity is often the time when meaning making really starts. Driver (1983, p. 49) comments:

It is common to see science lessons which end with the clearing up after the practical work is finished. The time for the important discussion of how the important experiences gained relate to the new ideas is missed. Activity by itself is not enough. It is the sense that is made of it that matters.

Gunstone (1991, p. 74) reiterates, "For practical work to have any serious effect on student theory reconstruction and linking of concepts in different ways, the students need to spend more time in interacting with ideas and less time interacting with apparatus".

\section{Using Practical Science to Help Students See Science as More Than Received Knowledge}

Let me now link some of these ideas from the literature to the situation in Pakistan. During a research project I was involved with I observed a science teacher explain the five major classifications of vertebrates as:

(a) Fish, (b) Birds, (c) Amphibians, (d) Reptiles and (e) Mammals 
Over two class periods the teacher brought in some preserved samples of dog-fish, flounder, and a frog - all preserved in formalin. In each case she explained the dominant characteristic of each species. Then she explained that human beings are vertebrates, and she brought in four bones from the vertebrate column of a human skeleton. She finished her lessons by demonstrating the characteristics of all the five classifications. The treatment given to classification was as if nature intended the animals to be divided in such a way. Interestingly, this science teacher was well aware of the Swedish biologist Linnaeus and his achievement in devising the classification system for animals, as it is a part of the microbiology curriculum at the undergraduate level (which she had studied). However, in her instruction it appeared as if the classification system was received from a 'divine authority' rather than something devised by a human scientist. By pointing out the human effort that went into the classification process an important aim of teaching students something of the nature of science might have been achieved. Talking of the theory behind the classification of vertebrates, could then have added to a bigger picture of biological knowledge. Instead the students viewed these two lessons as separate examples of fish, amphibians, reptiles, birds and mammals.

This brings us to the nexus of knowledge and authority in Pakistan. In Pakistan society, as in many other countries of the world, knowledge, and hence scientific knowledge, is seen to reside with authority (Fuller \& Snyder, 1991; Shumba, 1999). The concept of knowledge as truth, and 'truth is for all time', is a dominant way of thinking about science knowledge for many people (Krugly-Smolska, 1995). The idea of challenging authority is very difficult for Pakistani students in particular. Much of the knowledge in books is accepted without question. Questions in science such as, 'Why are animals classified in this manner?' are never raised. They are instead accepted as a fact, or as a truth. This is not only a problem in developing countries like Pakistan, but appears to be endemic even in developed countries. Lemke (1990, p. 175) goes so far as to comment that: "It is dangerous to society to have students leave school believing that science is a perfect means to absolute, objective truths, discovered by people of superhuman intelligence".

So Pakistan science teachers teach science in a way that adds to the 'mystique' (Lemke, 1990) or the 'mythology' of science (Smolicz \& Nunan, 1975). They seldom make it clear that science is a human endeavor, and therefore, subject to human frailties. Questions such as, 'What are good reasons for believing that?' are very rarely encounter in Pakistan science classrooms. Acceptance of authority as a source of knowledge, and hence not challenging the knowledge provided by the teacher, is thus deeply embedded in the culture of Pakistan schooling (Aubusson \& Watson, 1999).

\section{Is Science a Superior, Value-free and Stable Way of Knowing?}

In a similar way, science teachers that I have encountered in my role as a science teacher educator, generally see science as a body of knowledge based on empirical evidence. Science knowledge is then considered to be different from other kinds of 
knowledge because of its ability to yield empirical evidence. One can perform an experiment and 'prove' a claim in science, whereas one cannot do that in other forms of knowing such as religion. Pakistan science teachers thus lay a great deal of importance on experiments to 'discover the laws of science and develop scientific theory'. Generally, teachers see science as knowledge that is neutral and value-free, free from religious beliefs, the latter which falls within the realm of 'faith'.

Personally I do not view science as belonging to any religion or group, and like Pakistan's most famous physicist and only Nobel laureate Abdus Salam', I believe in maintaining a distance between science and religion (Hoodbhoy, 1998) ii $^{\mathrm{ii}}$. However, at the same time I acknowledge and value Sardar's vision, as quoted in Loo (1996, p. 288), of science as a human activity that is "subject to the moral philosophy of Islam", and envisage a halalii environmentally-friendly science that promotes social justice and public interest. The key issue of the control of science by the community of scientists, or a higher moral authority, in my view needs rethinking. But the concept of the nature of science is essential for school science. Furthermore, there is a paucity of literature that discusses the nature of science from an Islamic perspective. Haidar (1999, p. 808), however, summarized the fundamental Islamic beliefs about the nature of science:

The purpose of science is to discover God's wisdom in the universe; knowledge can be acquired by the scientific method as well as by other means, e.g., revelation; truth is not absolute, we see only what God permits us to see; and the only absolute truth is what God knows.

It is important to emphasize that these views may represent just a particular point of view, and that other denominations of Islam may have views that are somewhat different. However, in Pakistan, these views would certainly find a fair degree of acceptance. This is an important element to consider in response to the work of Lederman and Niess (1997), who question the ability of science teachers holding traditional views about science, to execute reform in science education. Does this mean that societies (not only Islamic societies) that espouse traditional views cannot reform science education? Or does it mean that science reforms need to adjust to belief systems in these parts of the world? Fuller (1997) explains the Islamic perspective about the nature of science, saying that Muslim thinkers question the sharp distinction that Western philosophers draw between episteme and ethics, and do not espouse a view of science that is value-free. Muslims view science as a knowledge that should be pursued for universal human good rather than for its own sake.

\section{A WAY FORWARD}

\section{Teaching Science: A Balancing Act}

Science teaching is characterized by a number of tensions. Tension between a desire to teach for understanding, and the need to complete the syllabus. Tension 
between a need to see that all students 'succeed' in the Board exams, and teaching for understanding. But teaching for success in examinations, and teaching for understanding ought not to be different, or have mutually exclusive goals. But in the less than ideal top-down, centralized examination system prevailing in Pakistan, it seems that skills needed to pass examinations are valued above understanding. Science holds the key to entry into fields such as medicine, engineering and computer science, which are highly valued in Pakistan. Hence, science marks are used as a 'weeders' to select students who can or cannot study science. These tensions are exacerbated in the teaching of science (and mathematics) as compared to subjects such as social studies and Islam.

Pakistan is a developing country, and has the ethos of a traditional Muslim society where conceptions of knowledge are very different from those prevalent in the modern and postmodern developed countries. In Pakistan, like many other developing nations, knowledge is seen to lie with authority and tradition (Shumba, 1999). Within such a framework students find it almost impossible to question and challenge their teachers - teachers are seen as the source of knowledge. In the same way, teachers themselves find it difficult to challenge authority, and are inclined to perform their duties in line with the dictates from 'above'. This contrasts markedly with modern views of teaching science, for example, inquirybased learning, that requires students to construct their own knowledge and challenge and question traditional ways of knowing. Non-traditional modes of teaching also envisage a different role for a teacher, removing the teacher from the center of the classroom as the source of knowledge or the knower, and giving at least some power to the learner. The teacher's role then would become that of a facilitator, a part rather than the whole of the learning environment. This would clearly constitute a huge change in teachers', students', parents', and administrators' views of teachers and teaching and learning in Pakistan. I believe that this issue needs to be tackled much more seriously at the teacher education level than is being done at the present.

\section{Knowledge of Subject Matter Is Not Enough}

I suggest here that a teacher having strong content knowledge is an essential but not a sufficient condition, to ensure good teaching. Even if teachers have a good understanding of science, they may not know it in ways that help them to 'hear' their students, select appropriate activities and enhance student understanding. In Pakistan, a very large number of teachers, particularly those employed in private institutions, are not trained teachers. Additionally, the kind of teacher training available is so theoretical in nature that does not meet the needs of teachers. Thus there is something of a Catch-22 situation: teachers do not seek teacher education because the education and training does not meet their needs. School administrators do not insist on professional training for the same reason. As a consequence, teachers continue to use their own experiences as students as the basis for teaching. Thus the cycle continues. This cycle can be broken if teacher 
educators are seen to provide education that extends content knowledge, and also teaches how to present this knowledge in a pedagogically sound manner. One of the ways that might be done is to teach teachers using methods, activities and projects that they can use with their own students. This would expose teachers to new methods of learning, and having experienced these methods they might be more likely to use them in their own classes (Stofflett, 1994).

There is a basis to this suggestion in the literature. Research on science teachers' pedagogical content knowledge suggests that understanding of a subject matter and experience in teaching contributes to the development of pedagogical content knowledge (van Driel, Verloop \& Vos, 1998). Adams and Krockover (1997) report beginning science teachers' pedagogical content knowledge depends both on their experience as a learner and as a teacher. Hence, a system of in-school professional development for teachers that suits the particular context, culture and needs of the school could go a long way to helping teachers who have not been exposed to professional education.

There is increasing evidence in the literature (e.g., Hodson, 1996, Nakhleh et al., 2002; Wellington, 2000) that practical work as currently conducted in both developed and developing countries does not necessarily help teachers achieve curricular goals. Open-ended investigations around relevant issues, project work, discussions, using reading and writing to learn science (Glynn \& Muth, 1994) can enhance science learning - sometimes more than structured hands-on science activities. In Pakistan, teachers use demonstrations as their preferred model for bringing practical activities into the science room. A slight modification in the manner in which demonstrations are conducted, for example, incorporating activities like prediction-observation-explanation (Gunstone, 1991) may increase the effectiveness of demonstrations. However, the greatest challenge lies not in developing curricula and new ideas, but in supporting teachers to implement them and to further refine them to suit their particular needs and the needs of their students.

\section{ACKNOWLEDGEMENT}

This paper has been developed from the work done as part of my doctoral dissertation, and my work as a teacher educator at the Aga Khan University.

\section{NOTES}

\footnotetext{
i Abdus Salam received the Nobel Prize in 1979 with Steven Weinberg and Sheldon Glashow for developing the unified theory of elementary particles.

${ }^{\text {ii }}$ However, there are other Islamic philosophers, such as Jaafar Sheikh Idris (1987), who believe in the concept of Islamic Science.

iii That which is legitimate or accepted in the Quran.
} 


\section{REFERENCES AND BIBLIOGRAPHY}

Asian Development Bank. (1988). Impact evaluation study of the secondary science education projects. Nepal, Bangladesh \& Pakistan. ADB.

Aubusson, P.J., \& Watson, K. (1999). Issues and problems related to science curriculum implementation in Pakistan: Perceptions of three Pakistani curriculum managers. Science Education, $83,603-620$.

Driver, R. (1994). The fallacy of induction in science teaching. In R. Levinson (Ed.), Teaching science (pp. 41-48). London: Routledge

Driver, R. (1983). The pupil as scientist? Milton Keynes, UK: Open University Press.

Chalmers, A.F. (1999). What is this thing called science? (3rd ed.). Buckingham, UK: Open University Press.

Fuller, B., \& Snyder, C.W. (1991). Vocal teachers, silent pupils? Life in a Botswana classroom. Comparative Education Review, 35, 274-293.

Fuller, S. (1997). Western science from the outside in: The view from Islam and Japan. In S. Fuller (Ed.), Science (pp. 106-136). Buckingham, UK: Open University Press.

Glynn, S.M., \& Muth, K.D. (1994). Reading and writing to learn science: Achieving scientific literacy. Journal of Research in Science Teaching, 31(9), 1057-1073.

Gunstone, R.F. (1991). Reconstructing theory from practical experience. In B. Woolnough (Ed.), Practical science: The role and reality of practical work in school science (pp. 67-77). Milton Keynes, UK: Open University Press.

Haidar, A.H. (1999). Emirates pre-service and in-service teachers' views about the nature of science. International Journal of Science Education, 21(8), 807-822.

Halai, N. (2002). Munazza's story: Understanding science teaching and conceptions of the nature of science in Pakistan through a life history study. Unpublished $\mathrm{PhD}$ dissertation, University of Toronto.

Hodson, D. (1998). Teaching and learning science: Towards a personalized approach. Philadelphia, PA: Open University Press.

Hodson, D. (1990). A critical look at practical work in school science. School Science Review, 70(256), 33-64.

Hodson, D. (1996). Laboratory work as scientific method: Three decades of confusion and distortion. Journal of Curriculum Studies, 28(2), 115-135.

Hoodbhoy, P. (1998). Salam, science and secularism. Retrieved 10 April 2001, from http://www.chowk.com/UniversityAve/hoodbhoy jan0598.html.

Iqbal, H.M., \& Mahmood, N. (2000). Science teacher education in Pakistan. In S.K. Abell (Ed.), Science teacher education: An international perspective (pp. 75-92). Boston: Kluwer.

Krugly-Smolska, E. (1995). Cultural influences in science education. International Journal of Science Education, 17(1), 45-58.

Lemke, J.L. (1990). Talking science: Language, learning, and values. Norwood, NJ: Ablex.

Malinowski, B. (1948). Magic, science and religion. Boston: Beacon.

Millar, R. (1998). Rhetoric and reality: What practical work in science education is really for. In J. Wellington (Ed.), Practical work in science: Which way now? (pp. 16-32). London: Routledge.

Nakhleh, M.B., Polles, J., \& Malina, E. (2002). Learning chemistry in a laboratory environment. In J.K. Gilbert, O. De Jong, D.F. Treagust \& J.H. Van Driel (Eds.), Chemical education: Towards researchbased practice (pp. 69-94). Dordrecht: Kluwer

Lederman, N.G., \& Niess, M.L. (1997). Editorial: The nature of science: Naturally? School Science and Mathematics, 97(1), 1-2.

Loo, S.P. (1996). The four horsemen of Islamic science: A critical analysis. International Journal of Science Education, 18(3), 285-294.

Social Policy \& Development Centre. (2002-03). State of science education. Social development in Pakistan - Annual Review 2002-03. SPDC.

Shumba, O. (1999). Relationship between secondary science teachers' orientation to traditional culture and beliefs concerning science instructional ideology. Journal of Research in Science Teaching, 36(3), 333-355.

Smolicz, J.J., \& Nunan, E.E. (1975). The philosophical and sociological foundations of science education: The demythologizing of school science. Studies in Science Education, 2, 101-143. 


\title{
CURRICULUM REFORM IN PAKISTAN SCIENCE EDUCATION
}

Roth, W.M. (1995). Authentic school science: Knowing and learning in open-inquiry science laboratories. Boston: Kluwer.

Tasker, R., \& Osborne, R. (1985). Science teaching and science learning. In R. Osborne \& P. Freyberg (Eds.), Learning in science: The implications of children's science (pp. 15-27). Auckland, New Zealand: Heinemann.

Warwick, D.P., \& Reimers, F. (1995). Hope or despair? Learning in Pakistan's primary schools. Wesport, CN: Praeger/Greenwood.

Wellington, J. (2000). Teaching and learning secondary science: Contemporary issues and practical approaches. London: Routledge.

Wellington, J. (1998). Practical work in science: Time for a reappraisal. In J. Wellington (Ed.), Practical work in school science (pp. 3-15). London: Routledge.

Wheatley, G.H. (1991). Constructivist perspectives on science and mathematics learning. Science Education, 75(1), 9-21.

World Bank. (2007). Pakistan: Data, projects and research. Retrieved 5 September 2007, from http://www.worldbank.org.pk/WBSITE/EXTERNAL/COUNTRIES/SOUTHASIAEXT/PAKISTA NEXTN/0,,menuPK:293057 pagePK:141159 piPK:141110 theSitePK:293052,00.html

\section{AFFILIATION}

\author{
Nelofer Halai \\ Institute for Educational Development \\ Aga Khan University \\ Pakistan
}


